\title{
Lifestyle factors influencing bone health in young adult women in Saudi Arabia.
}

\author{
Lina F Hammad ${ }^{1}$, Nada Benajiba ${ }^{2}$
}

1. Department of Radiological Sciences, College of Applied Medical Sciences King Saud University, Riyadh, Saudi Arabia.

2. Clinical Nutrition Program - Department of Health Sciences, College of Health and Rehabilitation Sciences, Princess Nourah Bint Abdulrahman University, Riyadh, Saudi Arabia.

\begin{abstract}
Aim: To analyze risk factors leading to osteopenia and osteoporosis among young female students.

Methods: Quantitative Ultrasonography measurements were performed in the calcaneal region of 101 young Saudi females. Dietary habits, exercising and sun exposure were assessed using questionnaires. The association between the different studied factors was assessed by Pearson test and multiple linear regression model.

Results: Participants diagnosed with either osteopenia or osteoporosis $(>33 \%$.) showed significant higher soft drinks consumption, reduced exercise, limited intake of milk and dairy products, calcium and vitamin D supplementation compared to the healthy group. Multiple regression analysis showed that T-score and Z-score were negatively associated with soft drink intake and positively associated with exercising, milk and dairy products consumption, and calcium and vitamin D supplementation use $(\mathrm{p}<0.05)$

Conclusion: High soft drink intake, lack of exercising and limited calcium and vitamin D supplementation are the combined lifestyle factors leading to osteopenia and osteoporosis among young Saudi females. These findings might serve as a basis of nutrition education intervention to promote healthy bones among this population.
\end{abstract}

Keywords: Lifestyle factors, osteoporosis, osteopenia, young women, Saudi Arabia.

DOI: https://dx.doi.org/10.4314/ahs.v17i2.28

Cite as: Hammad LF, Benajiba N. Lifestyle factors influencing on bone bealth in young adult women in Saudi Arabia. Afri Health Sci. 2017;17(2): 524-531. bttps:/ / dx.doi.org/10.4314/abs.v17i2.28

\section{Introduction}

Osteoporosis is considered a public health problem in Saudi ${ }^{1}$. It mainly affects pre-menopausal and post-menopausal women for which most of the research on osteoporosis has been based. Oomeen and Alzahrani reported that $58 \%$ of Saudi women between the ages, $40-75$ years were diagnosed with osteopenia $(40 \%)$ or osteoporosis $(15 \%)^{2}$. In this respect, it was also reported that the prevalence of osteopenia and osteoporosis among women ( $\geq 50$ years) at the lumbar spine were $31 \%$ and $40 \%$, re-
Corresponding author:
Nada Benajiba,
Clinical Nutrition Program,
Department of Health Sciences,
College of Health and Rehabilitation Sciences,
Princess Nourah Bint Abdulrahman University,
Riyadh, Saudi Arabia.
Tel: 00966118240752
Email: benajibanada@gmail.com

spectively ${ }^{3}$. A recent pilot study among female University students (average age 21 years) revealed that this young population might also suffer from this bone health condition ${ }^{4}$. Results of this pilot study indicated that osteoporosis was prevalent among $5 \%$ of the participants in the spine area. They also showed that the prevalence of osteopenia among this population was $37 \%$ and $34 \%$ in the spine and the neck of the femur area, respectively. This high prevalence of osteopenia among young adult females emphasizes the urgent need of an early intervention to prevent the development of osteoporosis in later life $^{4}$.

Osteoporosis and osteopenia are skeletal conditions characterized by a reduction in the bone mass density predisposing to an increased risk of fractures ${ }^{5}$. Peak bone mass is achieved at its $90 \%$ by late adolescence ${ }^{6}$. Therefore, prevention of osteopenia and osteoporosis should begin at young adult age which is considered as the most adequate time to invest in bone health. In addition, they are considered as lifestyle diseases. This means that adopting healthy lifestyles such as adequate diet, sun exposure 
and exercising might help prevent the development and progress of osteopenia and osteoporosis. Alotaibi et al. ${ }^{7}$ indicated that the first step in the prevention of osteoporosis in women should take the first step of creating an awareness among them about the risk factors of this disease. Such awareness can only be achieved by the understanding of the underlying factors leading to osteopenia and osteoporosis among this population ${ }^{7}$. Thus, the aim of this research was to study the underlying risk factors leading to osteopenia and osteoporosis among young female students. This would help plan for adequate and necessary preventive measures.

\section{Materials and methods \\ Study design}

The study was carried out at King Saud University campus, from February to September 2015. It was a cross sectional study. An announcement was made at the university and interested young females students (age range 20-24.9 years) were recruited. A total of 110 young females (age range 20-24.9 years) participated in the study. They had no previous history of fracture or known bone disease. A standardized questionnaire was used for each participant in the study. The following exclusion criteria was applied: using drugs interacting with calcium metabolism; suffering from any health condition affecting bone metabolism; having a history of fracture or major systemic disorder; being pregnant or at any terminal illness stage.101 young female were considered after application of exclusion criteria. Each of the participants were requested to sign an informed consent from before measurements were taken. The study was approved by the Research Ethics Committee of the University (Ethics No. CAMS18/3S36), and was performed according to principles of Helsinki declaration.

\section{Quantitative Ultrasonography (QUS) measurements}

Lunar Achilles Insight TM - GE Healthcare was used to take the measurements. It is a heel water-bath ultrasound system, which generates a band of frequencies from 200 to $600 \mathrm{kHz}$. Quantitative Ultrasonography (QUS) Stiffness index (automatically calculated from broadband ultrasound attenuation and the speed of sound). Reliability of QUS has been confirmed as technique of high sensitivity to detect both osteopenia and osteoporosis ${ }^{8}$, and as good as bone mineral density (BMD) assessed by DXA (Dual-emission X-ray Absorptiometry) in predicting fracture risk ${ }^{1}$. Daily quality control was performed by the use of the quality phantom. During the study period, the quality control test and measurements were taken independent foot before any data collection. The stiffness index was used to calculate both Z-score, which compares the $\mathrm{BMD}$, to what might be expected in someone of same age and body size of the study population, and T-score based on a healthy young adult reference population, using a standard protocol provided by the producer. T-score of $>-1$ was classified as normal, a score of $<$ -0.1 and $>-2.5$ was classified as being at risk of having osteopenia while a T-score of $<-2.5$ was classified as at risk of having osteoporosis as per diagnosis criteria for osteoporosis set by World Health Organization?.

\section{Anthropometric measurements and lifestyle habits of the population}

Weight and height were measured by the investigators, after which the body mass index (BMI) $\left(\mathrm{kg} / \mathrm{m}^{2}\right)$ was calculated. Subjects were afterwards classified based on the WHO guidelines ${ }^{10}$. Underweight: $<18.50 \mathrm{~kg} / \mathrm{m}^{2}$, Normal: $18.50-24.99 \mathrm{~kg} / \mathrm{m}^{2}$, overweight $\geq 25.00 \mathrm{~kg} / \mathrm{m}^{2}$ and obese $\geq 30.00 \mathrm{~kg} / \mathrm{m}^{2}$. The assessment of lifestyle factors was conducted using questionnaires, asking respondents to answer either no or yes on the following: smoking, exercising, sun exposure, calcium and vitamin D supplements intake. Dietary intake of animal protein, soft drinks, and dairy products were assessed by a simple food-frequency questionnaire, indicating the number of times per week that these food were eaten and whether the portion size was large in the case of soft drinks. These lifestyle factors were selected because they are known to have strong influence on bone health ${ }^{11}$.

\section{Statistical analysis}

Results were presented in the form of percentages, means and standard deviation. T-test and ANOVA test were used to assess the difference between the groups. Z-test for proportion was used to assess the difference in percentage between the groups. The difference was considered significant at a $\mathrm{p}<0.05$. In order to obtain factors with significant association to stiffness index, T-score or Z-score, a multiple linear regression analysis was used. In the first step, Pearson correlation coefficient was tested to examine the presence of an association between the different studied factors, and the Stiffness index and T-score and Z-score values in the calcaneus. Then, in the second step, factors with a significant correlation $(p<0.05)$ were entered into multiple linear regression model and associa- 
tion was considered as significant when the $\mathrm{p}$ was $<0.05$. Statistical analysis was performed using SPSS software (Version 24.0).

\section{Results}

The general characteristics of the studied population are presented in Table 1. Mean age was $21.34 \pm 0.83$ years and mean BMI was $22.21 \pm 3.66 \mathrm{~kg} / \mathrm{m}^{2} .95 \%$ of the students who participated in this study have a monthly income higher than 6000 SAR (Saudi Riyals).

Table 1: General characteristics of the studied population

\begin{tabular}{|c|c|}
\hline Parameter & Mean \pm SD or \% (N=101) \\
\hline Age (year) & $21.34 \pm 0.83$ \\
\hline Height (m) & $1.58 \pm 0.06$ \\
\hline Weight (kg) & $55.87 \pm 9.45$ \\
\hline BMI (Kg/m $\mathbf{m}^{2}$ ) & $22.21 \pm 3.66$ \\
\hline Monthly income (Saudi Riyals (SAR)) & \\
5500-6000 SAR & $4 \%$ \\
> $\mathbf{6 0 0 0 ~ S A R ~}$ & $95 \%$ \\
\hline
\end{tabular}

BMI: Body Mass Index $\left(\mathrm{kg} / \mathrm{m}^{2}\right)$. Data are shown as mean \pm SD for age, height, weight and $\mathrm{BMI}$ and in percentage of the total population for the monthly income.

More than a third of the participants were diagnosed with either osteopenia or osteoporosis $(\approx 33 \%$ and three percent respectively) (Table 2).

Table 2. Stiffness index in the calcaneus in the studied population based on the $\mathrm{T}$-score classification

\begin{tabular}{|l|c|c|c|c|}
\hline Stiffness index & $\begin{array}{c}\mathbf{N} \\
\text { (Total } \mathbf{n}=\mathbf{1 0 1})\end{array}$ & $\%$ & \multicolumn{2}{|c|}{ Mean \pm SD } \\
\hline Normal & 66 & 65.3 & $100.95 \pm 16.2$ & \multirow{2}{*}{$p=0.000$} \\
\hline Osteopenic & 32 & 31.2 & $81.52 \pm 15.65$ & \\
\hline Osteoporotic & 3 & 2.9 & $54.33 \pm 4.93$ & \\
\hline
\end{tabular}

T-score classification based on WHO guidelines ${ }^{9}$. Normal $=$ T-score $>-1$,

Osteopenic $=\mathrm{T}$-score $(-1$ to -2.5$)$, and Osteoporotic $=\mathrm{T}$-score $<-2.5$. Data are shown as percentage of the total population $(n=101)$ and as mean \pm SD for T-score.

Distribution of the study population according to lifestyle factors and the bone health status (based on T-score) is presented in table 3. Data demonstrated that the majority of the sample studied had a normal BMI (about $68 \%$ of the total population), while about $14 \%$ were either underweight or overweight and $4 \%$ were obese. The majority of the sample size in this study stated that they did not smoke (92\%), whereas dairy and milk consumption was found to be low as $45.5 \%$ were having it less than twice a week. The proportion of students consuming milk less than twice a week was significantly higher in osteoporotic-osteopenic group compared to normal group $(60 \%$ versus $37.8 \%, p=0.03)$. More than half of the study sample size $(59 \%)$ stated that they did not expose themselves to sun rays; this percentage was increased in the osteoporotic-osteopenic group to $\approx 71 \%$. In addi- tion, $87 \%$ of the sample studied stated that they did not take calcium and vitamin D supplements; this percentage increased to about $97 \%$ in the osteoporotic-osteopenic group and was significantly higher compared to normal group $(81 \%, p=0.02)$. The soft drink consumption within the sample was generally high, about three-quarters of the population consumed it either moderately ( $>2$ cans / week) or frequently (>than 3 and large cans/day). Rare consumption (<2 times/week) was significantly higher in normal group compared to the osteoporotic-osteopenic group. In contrast, frequent consumption (three cans and more/day) was higher in the osteoporotic-osteopenic group compared to normal subjects $(34 \%$ and $7.5 \%$ respectively, $\mathrm{p}=0.01)$, Similar findings were found when asked about the exercising habits, $77 \%$ of the osteoporotic-osteopenic group stated that they did not exercise compared to $53 \%$ of the normal group. 
Table 3: Influencing factors on the bone health status (based on the T-score classification)

\begin{tabular}{|c|c|c|c|c|}
\hline \multirow[b]{2}{*}{ Factor } & \multirow{2}{*}{$\begin{array}{r}\text { Total population } \\
\begin{array}{c}\% \\
(\mathrm{n}=101)\end{array}\end{array}$} & \multicolumn{3}{|c|}{$\begin{array}{c}\text { Bone health status } \\
\text { (based on the T-score) }\end{array}$} \\
\hline & & $\begin{array}{c}\text { Normal } \\
\%(\mathrm{n}=66)\end{array}$ & $\begin{array}{c}\text { Osteoporotic - Osteopenic } \\
\%(\mathrm{n}=35)\end{array}$ & $p$-value \\
\hline $\begin{array}{l}\text { BMI category } \\
\text { Underweight } \\
\text { Normal } \\
\text { Overweight } \\
\text { Obese }\end{array}$ & $\begin{array}{c}13.8 \\
68.3 \\
13.8 \\
3.9 \\
\end{array}$ & $\begin{array}{c}12.1 \\
74.2 \\
10.6 \\
3.0\end{array}$ & $\begin{array}{c}20 \\
68.6 \\
11.4 \\
0\end{array}$ & $\begin{array}{l}0.2 \\
0.5 \\
0.8 \\
0.2\end{array}$ \\
\hline $\begin{array}{c}\text { Smoking } \\
\text { No } \\
\text { Yes }\end{array}$ & $\begin{array}{c}92.0 \\
8.0\end{array}$ & $\begin{array}{c}90.9 \\
9.1\end{array}$ & $\begin{array}{c}94.1 \\
5.8\end{array}$ & $\begin{array}{l}0.5 \\
0.5\end{array}$ \\
\hline $\begin{array}{ll}\text { Dairy and milk consumption } \\
-\quad \text { Rare }(<2 \text { times/week) } \\
-\quad \text { Moderate (2 times/week) } \\
-\quad \text { Frequent (3-5 times/week) } \\
\end{array}$ & $\begin{array}{r}45.5 \\
45.5 \\
8.9 \\
\end{array}$ & $\begin{array}{l}37.8 \\
51.5 \\
10.7\end{array}$ & $\begin{array}{c}60 \\
34.3 \\
0.5 \\
\end{array}$ & $\begin{array}{c}0.03 \\
0.09 \\
0.4\end{array}$ \\
\hline $\begin{array}{l}\text { Sun exposure } \\
\text { No } \\
\text { Yes }\end{array}$ & $\begin{array}{l}59.1 \\
40.8\end{array}$ & $\begin{array}{l}53.8 \\
46.1\end{array}$ & $\begin{array}{l}70.5 \\
29.4\end{array}$ & $\begin{array}{l}0.07 \\
0.07\end{array}$ \\
\hline $\begin{array}{l}\text { Calcium and vitamin D supplements } \\
\text { No } \\
\text { Yes }\end{array}$ & $\begin{array}{l}86.8 \\
13.3\end{array}$ & $\begin{array}{l}81.5 \\
18.4\end{array}$ & $\begin{array}{c}97.1 \\
2.9\end{array}$ & $\begin{array}{l}0.02 \\
0.02\end{array}$ \\
\hline $\begin{array}{ll}\text { Animal protein consumption } \\
-\quad \text { Rare }(<2 \text { times/week) } \\
-\quad \text { Moderate (2-4 times/week) } \\
-\quad \text { Frequent (daily) }\end{array}$ & $\begin{array}{l}27.0 \\
40.0 \\
33.0\end{array}$ & $\begin{array}{l}21.2 \\
42.4 \\
36.3\end{array}$ & $\begin{array}{l}38.3 \\
35.2 \\
26.5\end{array}$ & $\begin{array}{l}0.08 \\
0.6 \\
0.2\end{array}$ \\
\hline $\begin{array}{ll}\text { Soft drinks consumption } \\
-\quad \text { Rare }(<1 \text { can/day) } \\
-\quad \text { Moderate }(>2 \text { cans/day) } \\
-\quad \text { Frequent }(>3 \text { and large cans/day })\end{array}$ & $\begin{array}{l}37.0 \\
46.0 \\
17.0\end{array}$ & $\begin{array}{c}46.9 \\
43.9 \\
7.5 \\
\end{array}$ & $\begin{array}{l}17.1 \\
48.6 \\
34.3\end{array}$ & $\begin{array}{c}0.03 \\
0.6 \\
0.01\end{array}$ \\
\hline $\begin{array}{l}\text { Exercising } \\
\text { No } \\
\text { Yes }\end{array}$ & $\begin{array}{l}61.3 \\
38.6\end{array}$ & $\begin{array}{l}53.0 \\
46.9\end{array}$ & $\begin{array}{l}77.1 \\
22.9\end{array}$ & $\begin{array}{l}0.01 \\
0.01\end{array}$ \\
\hline
\end{tabular}

BMI $\left(\mathrm{kg} / \mathrm{m}^{2}\right)=$ Body mass index. BMI categorization is based on the WHO guidelines ${ }^{10}$ : Underweight: $<18.50 \mathrm{~kg} / \mathrm{m}^{2}, \mathrm{Normal}: 18.50-24.99 \mathrm{~kg} / \mathrm{m}^{2}$, Overweight $\geq 25.00$ PubMed $\mathrm{kg} / \mathrm{m}^{2}$ and obese $\geq 30.00$ PubMed $\mathrm{kg} / \mathrm{m}^{2}$. Data are shown as percentage of the total population ( $\mathrm{n}=101$ ) or of group based on the bone health status ( $\mathrm{n}=66$ for normal group and $\mathrm{n}=35$ for Osteoporotic - Osteopenic group).

Table 4 summarizes the averages of the three indicator Z-score, T-score and stiffness index at the calcaneal region according to the studied lifestyle factors. For BMI, significant difference was obtained for stiffness index only $(\mathrm{p}=0.02)$. The average of the three indicators went higher with the increased frequency of consumption of dairy products and animal protein; however, such an aug- ment was not convincingly significant. In contrast, the higher the soft drinks consumption frequency the lower are the average of all the indicators. Data from rare to frequent consumption of soft drinks were -0.12 to 1.03 for Z-score, from -0.15 to -1.06 for T-score and from 97.6 to 86.6 for stiffness index, respectively. The difference was significant for Z-score and T-score but not significant for the stiffness index.

Table 4: Mean and SD of Z-score, T-score and Stiffness index according to lifestyle factors

\begin{tabular}{|c|c|c|c|c|c|}
\hline Lifestyle factor & Z-Score & & T-Score & & Stiffness index Achillis \\
\hline $\begin{array}{l}\text { BMI category } \\
\text { Underweight } \\
\text { Normal } \\
\text { Overweight } \\
\text { Obese }\end{array}$ & $\begin{array}{l}-0.94 \pm 0.9 \\
-0.27 \pm 1.1 \\
-0.66 \pm 1.1 \\
-1.08 \pm 1.0\end{array}$ & $p=0.1$ & $\begin{array}{l}-0.97 \pm 0.9 \\
-0.31 \pm 0.5 \\
-0.65 \pm 1.1 \\
-1.13 \pm 1.0\end{array}$ & $p=0.1$ & $\begin{array}{l}82.64 \pm 20.3 \\
85.00 \pm 26.9 \\
94.50 \pm 21.0 \\
75.25 \pm 11.1\end{array}$ \\
\hline $\begin{array}{l}\text { Smoking } \\
\text { No } \\
\text { Yes }\end{array}$ & $\begin{array}{l}-0.44 \pm 1.1 \\
-0.39 \pm 1.0\end{array}$ & $p=0.8$ & $\begin{array}{l}-0.47 \pm 1.1- \\
0.45 \pm 1.0\end{array}$ & $p=0.8$ & $\begin{array}{l}92.99 \pm 19.1 \\
98.00 \pm 24.2\end{array}$ \\
\hline $\begin{array}{l}\text { Dairy and milk consumption } \\
-\quad \text { Rare }(<2 \text { times/week) } \\
-\quad \text { Moderate (2 times/week) } \\
\text { Frequent (3-5 times/week) }\end{array}$ & $\begin{array}{l}-0.69 \pm 1.0 \\
-0.31 \pm 1.3 \\
0.07 \pm 1.1\end{array}$ & $p=0.1$ & $\begin{array}{l}-0.72 \pm 0.9 \\
-0.35 \pm 1.2 \\
0.12 \pm 1.1\end{array}$ & $p=0.1$ & $\begin{array}{l}90.33 \pm 17.0 \\
95.33 \pm 21.6 \\
97.22 \pm 19.0\end{array}$ \\
\hline $\begin{array}{l}\text { Sun Exposure } \\
\text { No } \\
\text { Yes }\end{array}$ & $\begin{array}{l}-0.56 \pm 1.2 \\
-0.27 \pm 1.1\end{array}$ & $p=0.5$ & $\begin{array}{l}-0.58 \pm 1.2 \\
-0.31 \pm 1.1\end{array}$ & $p=0.2$ & $\begin{array}{l}91.36 \pm 20.2 \\
95.58 \pm 18.3\end{array}$ \\
\hline $\begin{array}{c}\text { Vitamin D and Ca supplement } \\
\text { No } \\
\text { Yes }\end{array}$ & $\begin{array}{l}-0.55 \pm 1.1 \\
0.27 \pm 1.1\end{array}$ & $p=0.03$ & $\begin{array}{l}-0.58 \pm 1.1 \\
0.22 \pm 1.2\end{array}$ & $p=0.02$ & $\begin{array}{l}92.10 \pm 18.9 \\
101.15 \pm 22.4\end{array}$ \\
\hline $\begin{array}{l}\text { Animal protein consumption } \\
\text { Rare (<2 times/week) } \\
\text { Moderate ( } 2-4 \text { times/week) } \\
\text { Frequent (daily) }\end{array}$ & $\begin{array}{l}-0.69 \pm 0.9 \\
-0.41 \pm 1.3 \\
-0.31 \pm 1.1\end{array}$ & $p=0.3$ & $\begin{array}{l}-0.69 \pm 0.9 \\
-0.44 \pm 1.3 \\
-0.31 \pm 1.1\end{array}$ & $p=0.3$ & $\begin{array}{l}89.89 \pm 18.8 \\
94.28 \pm 20.9 \\
93.94 \pm 18.1\end{array}$ \\
\hline $\begin{array}{l}\text { Soft drinks consumption } \\
\text { Rare }(<1 \text { can/day) } \\
\text { Moderate }(>2 \text { cans/day) } \\
\text { Frequent }(>3 \text { and large } \\
\text { cans / day) }\end{array}$ & $\begin{array}{l}-0.12 \pm 0.9 \\
-0.48 \pm 1.3 \\
-1.03 \pm 1.0\end{array}$ & $p=0.02$ & $\begin{array}{l}-0.15 \pm 0.9 \\
-0.52 \pm 1.3 \\
-1.06 \pm 1.0\end{array}$ & $p=0.02$ & $\begin{array}{l}97.59 \pm 15.4 \\
92.30 \pm 20.8 \\
86.59 \pm 22.5\end{array}$ \\
\hline $\begin{array}{l}\text { Exercise } \\
\text { No } \\
\text { Yes }\end{array}$ & $\begin{array}{l}-0.65 \pm 1.2 \\
-0.14 \pm 1.0\end{array}$ & $p=0.02$ & $\begin{array}{l}-0.68 \pm 1.2 \\
-0.17 \pm 1.0\end{array}$ & $p=0.02$ & $\begin{array}{l}90.19 \pm 20.7 \\
98.03 \pm 16.1\end{array}$ \\
\hline
\end{tabular}

$\mathrm{BMI}=$ Body mass index. BMI categorization is based on the WHO guidelines ${ }^{10}:$ Underweight: $<18.50 \mathrm{~kg} / \mathrm{m}^{2}$,

Normal: $18.50-24.99 \mathrm{~kg} / \mathrm{m}^{2}$, Overweight $\geq 25.00$ PubMed kg/m² and obese $\geq 30.00$ PubMed $\mathrm{kg} / \mathrm{m}^{2}$. Data are shown as mean $\pm S D$. 
No significant difference was observed in the case of sun exposure even when averages were higher when the answer was "yes". Vitamin D and $\mathrm{Ca}^{2+}$ supplement intakes were associated with significant increases in T-score, Z-score. Average of T-score and Z-score were -0.55 and -0.58 and respectively for group that was not taking supplements, and 0.27 and 0.22 for group that did. The average of the three indicators registered higher when performing the physical activity "yes" compared to "no". This was the only lifestyle factor where the difference was significant for T-score, Z-score as well as stiffness index. The Pearson correlation coefficient of Stiffness index, T-score and Z-score at the calcaneus with the different lifestyle factors is presented in table 5 .

Table 5: Correlation between stiffness indicators and lifestyle factors

\begin{tabular}{|c|c|c|c|c|c|c|}
\hline & \multicolumn{2}{|c|}{ Stiffness index } & \multicolumn{2}{|c|}{ T-score } & \multicolumn{2}{|c|}{ Z-score } \\
\hline & $r$ & $p$-value & $r$ & $p$-value & $r$ & $p$-value \\
\hline BMI $\left(\mathrm{Kg} / \mathrm{m}^{2}\right)$ & 0.24 & 0.01 & 0.17 & 0.08 & 0.17 & 0.09 \\
\hline Smoking & 0.07 & 0.4 & 0.01 & 0.9 & 0.01 & 0.9 \\
\hline $\begin{array}{l}\text { Milk and dairy } \\
\text { products consumption }\end{array}$ & 0.17 & 0.09 & 0.26 & 0.009 & 0.25 & 0.011 \\
\hline Sun Exposure & 0.11 & 0.33 & 0.12 & 0.26 & 0.13 & 0.24 \\
\hline $\begin{array}{l}\text { Calcium \& Vitamin D } \\
\text { supplements }\end{array}$ & 0.16 & 0.11 & 0.24 & 0.015 & 0.25 & 0.014 \\
\hline $\begin{array}{l}\text { Animal protein } \\
\text { consumption }\end{array}$ & -0.2 & 0.04 & -0.28 & 0.005 & -0.28 & 0.005 \\
\hline $\begin{array}{l}\text { Soft drinks } \\
\text { consumption }\end{array}$ & -0.2 & 0.02 & -0.28 & 0.003 & -0.28 & 0.002 \\
\hline Exercise & 0.08 & 0.4 & 0.14 & 0.16 & 0.14 & 0.15 \\
\hline
\end{tabular}

$\mathrm{BMI}=$ Body mass index.

Soft drinks consumption was the only factor negatively associated with the three parameters $(p<0.05)$. Stiffness index showed a significant positive correlation with BMI, while T-score and Z-score were positively correlated with exercising, calcium and vitamin D supplements intake, as well as milk and dairy products consumption.
The three models obtained from regression were significant ( $p<0.001)$, accounting for $6 \%$ in the case of stiffness index and $17.5 \%$ in both T-score and Z-score. BMI was the only factor associated with stiffness index. While T-score and Z-score were associated positively with exercising, calcium and vitamin D supplements intake, and negatively with soft drinks consumption. (Table 6). 
Table 6: Multiple linear regression models

\begin{tabular}{|c|c|c|c|c|c|c|}
\hline & b & SE & B & $p$-value & Partial $\mathbf{R}^{2}$ & $95.0 \%$ CI for $\mathrm{B}$ \\
\hline \multicolumn{7}{|l|}{ Stiffness index } \\
\hline Intercept & 77.072 & 13.381 & & .000 & & $50.51,103.63$ \\
\hline BMI & 1.094 & .518 & .208 & .037 & .209 & $.06,2.12$ \\
\hline $\begin{array}{l}\text { Soft drinks } \\
\text { consumption }\end{array}$ & -4.527 & 2.704 & -.165 & .097 & -.168 & $-9.89, .84$ \\
\hline \multicolumn{7}{|l|}{ T-score } \\
\hline Intercept & -1.977 & .647 & & .003 & & $-3.26,-.69$ \\
\hline $\begin{array}{l}\text { Milk and } \\
\text { dairy products } \\
\text { consumption }\end{array}$ & .321 & .168 & .184 & .059 & .194 & $-.01, .65$ \\
\hline $\begin{array}{l}\text { Calcium and vitamin D } \\
\text { supplement }\end{array}$ & .754 & .309 & .229 & .017 & .245 & $.14,1.37$ \\
\hline $\begin{array}{l}\text { Soft drinks } \\
\text { consumption }\end{array}$ & -.327 & .151 & -.207 & .034 & -.218 & $-.63,-.026$ \\
\hline Exercise & .518 & .218 & .223 & .020 & .239 & $.14,1.37$ \\
\hline \multicolumn{7}{|l|}{ Z-score } \\
\hline Intercept & -1.958 & .654 & & .004 & & $-3.26,-.66$ \\
\hline $\begin{array}{l}\text { Milk and } \\
\text { dairy products } \\
\text { consumption }\end{array}$ & .312 & .170 & .177 & .071 & .186 & $-.027, .65$ \\
\hline $\begin{array}{l}\text { Calcium and vitamin D } \\
\text { supplement }\end{array}$ & .774 & .312 & .232 & .015 & .249 & $.15,1.39$ \\
\hline $\begin{array}{l}\text { Soft drinks } \\
\text { consumption }\end{array}$ & -.328 & .153 & -.206 & .035 & -.217 & $-.63,-.024$ \\
\hline Exercise & .524 & .220 & .224 & .019 & .239 & $.09, .96$ \\
\hline
\end{tabular}

Stiffness index Achillis model summary: $\mathrm{F}=4.23, p=0.016, \mathrm{R}^{2}=0.07, \mathrm{SEE}=18.86, \mathrm{~T}$-score model summary: $\mathrm{F}=6.154, p=.000, \mathrm{R}^{2}=0.175, \mathrm{SEE}=1.02$, Z-score model summary: $\mathrm{F}=6.071 p=.000 \mathrm{R}^{2}=0.173$, SEE 1.03 .

\section{Discussion}

As osteoporosis is a public health problem among Saudi women, preventive measures at young adult age might be of interest to tackle this health condition. This aim of this study was to analyse lifestyle factors related to osteopenia and osteoporosis in young female Saudi women, in order to develop specific recommendations to help them develop adequate preventive behaviour.

In our study, we found a remarkable low consumption of milk and dairy products among young female (less than two times per week by $91 \%$ ), which is consistent with a previous study ${ }^{12}$. Our results indicated that the proportion of students consuming milk and dairy products less than two times a week was significantly lower in normal group compared to osteoporotic-osteopenic group. Furthermore, a significant positive correlation was found between T-score and Z-score, and the frequency of milk and dairy products consumption, $(r=0.26$ and $r=0.25$, respectively, $\mathrm{p}<0.05)$. Our findings corroborate previous findings that the higher the frequency of consuming dairy products the lower the prevalence of osteoporosis among the population ${ }^{13}$.
As with supplement use, percentage of students taking calcium and vitamin D supplementations were in general low among the total population, and lower among osteopenic-osteoporotic compared to normal group in this research. Moreover, the mean T-score, Z-score and Stiffness index were significantly higher among participants who were taking supplements. This data is in accordance with findings reporting the positive effects of calcium and vitamin $\mathrm{D}$ supplementations on reducing bone $\operatorname{loss}^{14-15}$.

According to Euromonitor International, Saudi Arabia is the largest consumer of soft drinks in the Middle East with the soft drinks market in continuous growth ${ }^{16}$. This fact is reflected in our study as we found that soft drinks were widely and frequently consumed by female University students. Indeed, $75 \%$ of the studied population in this research consumed soft drinks either moderately (more than two cans/week) or frequently (>than 3 and large cans/day). Our data showed that the higher the soft drinks consumption, the lower the average of T-score and Z-score. In addition, osteoporotic-osteopenic group showed more frequent consumption compared to normal 
group. Among the different dietary factors, soft drinks consumption was the most correlated to T-score and Z-score and influenced negatively on bone health $(\mathrm{r}=$ $0.28, \mathrm{p}<0.05$ ), which is consistent with previous studies. In addition, a negative correlation between milk and soft drinks consumption in this present study $(r=-0.22$, data not shown) corroborates previous findings as demonstrated by Fung et al. ${ }^{17}$.

In contrast to the previous dietary habits, animal protein intake was not found to be of significant influence on bone health among participants of the present study, although a difference in frequency of intake was observed, and registered a higher percentage of rare intake $(<2 /$ week) found among osteoporotic-osteopenic group. In a young adult Spanish population, Correa-Rodriguez and al. demonstrated that protein intake was weakly correlated with heel QUS measurement, and no significant correlation was obtained then protein intake as a factor was entered in multiple regression model ${ }^{18}$.

In our study, we found a high prevalence of physical inactivity among women (61\%). Rather sadly, this is a challenging reality to public health in Saudi Arabia as reported by previous studies ${ }^{14,19}$. This percentage of physically inactive young female increases to $77 \%$ in osteopenic-osteoporotic compared to $23 \%$ in normal group. In addition, mean of the stiffness index, T-score and Z-score was higher in the group of students who maintain a regular exercise. A significant correlation $(r=0.21, p<0.05)$ was also found between exercising and $\mathrm{T}$-score and Z-score. This data supports the evidence that physical activity could be considered as a way of preventing osteoporosis among young adults ${ }^{20}$.

Even if Saudi Arabia is considered a sunny country, we found that about $60 \%$ of the total population did not expose themselves to sunlight, with even higher percentages reaching as much as $70 \%$ among the osteopenic-osteoporotic group. Similar findings have been reported in previous studies ${ }^{7,14}$. This low rate of exposure to sunlight has been justified by lack of awareness, hot climate and limited out-door activities. In our study, this factor was weakly correlated to osteopenia and osteoporosis in the studied population, although it is well established that sun exposure helps maintain bone health by promoting vitamin $\mathrm{D}$ synthesis. This result could be explained by the fact that more accuracy about the frequency and duration of exposure to sun light was needed.

A possible original input of this study was the multi- factorial causes leading to osteopenia and osteoporosis among a young population of women. Understanding the context of this multi-factorial causes may help developing adequate intervention with focus on importance of adopting a healthy lifestyle based on performing regular physical activity, reducing the consumption of soft drinks as well as ensuring an adequate intake of vitamin $\mathrm{D}$ and calcium.

\section{Conclusion}

The present study documents that high intake of soft drinks, reduced physical activity, limited calcium and vitamin D supplementation use seem to be the main lifestyle factors leading to osteopenia and osteoporosis among young adult Saudi women. This data could be the basis for nutrition education intervention to improve lifestyle habits and promote healthy bones in later life.

\section{Limitations}

This research was a cross-sectional study aiming to provide a first insight of underlying factors leading to osteopenia and osteoporosis among young female students. One limitation was the small size of the studied population $(n=101)$. Thus, further investigations with a larger sample we anticipate, might provide an in-depth analysis and possible prediction of the contribution of each factor in the development of this bone health conditions.

\section{Acknowledgment}

This research project was supported by a grant from the "Research Center of the Female Scientific and Medical Colleges", Deanship of Scientific Research, King Saud University.

\section{Competing interest}

The Authors report no conflict of interest and was responsible for the content and writing of the paper.

\section{References}

1. Al-Saleh Y, Sulimani R, Sabico S, Raef H, Fouda M, Alshahrani F, et al. Guidelines for Osteoporosis in Saudi Arabia: Recommendations from the Saudi Osteoporosis Society. Annals Sandi Med. 2015; 35(1):1 PubMed -12. DOI: $10.5144 / 0256-4947.2015 .1$

2. Oommen A, AlZahrani I. Prevalence of osteoporosis and factors associated with osteoporosis in women above 40 years in the Northern Part of Saudi Arabia. 
Int J Res Med Sci. 2014; 2(1):274 PubMed -278. DOI: 10.5455/2320-6012.ijrms20140252

3. Alwahhabi B. Osteoporosis in Saudi Arabia. Saudi Med.J 2015; 36: 1149-1150 PubMed . DOI: 10.15537/ smj.2016.4.14776

4. Hammad L. Quantitative ultrasound measurements of stiffness index in young adult females. Arch Med. 2015; 5:1-4 PubMed . DOI: 10.3823/107

5. Bernabei R, Martone AM, Ortolani E, Landi F, Marzetti E. Screening, diagnosis and treatment of osteoporosis: a brief review. Clin Cases in Mineral Bone Metab. 2014; 11(3): 201-207. DOI : 10.1002/2327-6924.12134

6. Banu DA. Peak bone mineral density of Bangladeshi men and women. J Sci Tech Res. 2015 ; 4(11). Available from URL: http://www.ijstr.org/final-print/nov2015/ Peak-Bone-Mineral-Density-Of-Bangladeshi-Men-AndWomen.pdf

7. Al-Otaibi H. Osteoporosis Health Beliefs, Knowledge and Life Habits among Women in Saudi Arabia. J Prev Med. 2015; 5:236-243 PubMed . DOI: 10.4236/ ojpm.2015.56027

8. Hammad L. Measurements of bone mineral density and stiffness index in young Saudi females. Pak J Med Sci. 2016; 32 (2):399 PubMed -402. DOI: 10.12669/ pjims.322.9757

9. Guidelines for preclinical evaluation and clinical trials in osteoporosis. Geneva: World Health Organization; 1998 (WHO/DOC/68)

10. Obesity: Preventing and Managing the Global Epidemic. WHO Technical Report Series 894. Geneva: World Health Organization; 2000 (WHO/DOC/8-9). 11. Kling JM, Clarke BL, Sandhu NP. Osteoporosis Prevention, Screening, and Treatment: A Review. J Womens Health. 2014; 23(7). DOI : 10.1089/jwh.2013.4611

12. Al Qauhiz NM. Obesity among Saudi Female University Students: Dietary Habits and Health Behaviors. $J$ Egypt Public Health Assoc. 2010; 85 (1-2):45-59. Available from URL: http://www.epha.eg.net/pdf/n1-2-2010/3. pdf PubMed
13. Rizzoli R. Dairy products, yogurts, and bone health. Am J Clin Nutr. 2014; 99(suppl):1256S-62S. DOI: 10.3945/ajcn.113.073056

14. Mahboub SM, Al-Muammar MN, Elareefy AA. Evaluation of the Prevalence and Correlated Factors for Decreased Bone Mass Density among Pre- and Post-menopausal Educated Working Women in Saudi Arabia. J Health Popul Nutr. 2014; 32:513-519. Available from URL: https://www.ncbi.nlm.nih.gov/pmc/articles/ PMC4221457/pdf/jhpn0032-0513.pdf

15. Weaver CM, Alexander DD, Boushey CJ, Dawson-Hughes B, Lappe JM, LeBoff MS and al. Calcium plus vitamin D supplementation and risk of fractures: an updated meta-analysis from the National Osteoporosis Foundation. Osteoporosis Int. 2016; 27:367-376. PubMed DOI 10.1007/s00198-015-3386-5

16. Soft Drinks in Saudi Arabia. Euromonitor International Country report; 2015; pp. 1-7.

17. Fung T'T, Arasaratnam MH, Grodstein F, Katz JN, Rosner B, Willett WC and al. Soda consumption and risk of hip fractures in postmenopausal women in the Nurses' Health Study. Am J Clin Nutr. 2014; 100:953- PubMed ;8. DOI: $10.3945 /$ ajcn.114.083352

18. Correa-Rodriguez M, Rio-Valle JS, Gonzalez-Jimenez E, Rueda-Medina B. The Effects of Body Composition, Dietary Intake, and Physical Activity on Calcaneus Quantitative Ultrasound in Spanish Young Adults. Biol Res Nursing. 2016; e18(4) 439-444. DOI: 10.1177/1099800416634884

19. Al-Eisa ES, Al-Sobayel HI: Physical Activity and Health Beliefs among SaudiWomen. J Nutr Metab. 2012; Article ID 642187, 6 pages. Available from URL: http:/ / dx.doi.org/10.1155/2012/642187

20. Tønnesen R, Schwarz P, Hovind PH, Jensen LT. Physical exercise associated with improved BMD independently of sex and vitamin D levels in young adults. Eur J Appl Physiol. 2016; 116:1297-1304. PubMed ; DOI 10.1007/s00421-016-3383-1 